\title{
NOTES AND REVIEWS
}

\author{
WITCHCRAFT AND DEMONOLOGY - TOPICS, METHODS AND \\ TRENDS IN WITCHCRAFT RESEARCH IN HUNGARY, 2017*
}

Gábor Klaniczay and Éva Pócs, eds. 2017. Witchcraft and Demonology in Hungary and Transylvania. Palgrave Historical Studies in Witchcraft and Magic. Cham: Palgrave Macmillan

One of the most prominent achievements of the atelier for witchcraft research which has assembled around Éva Pócs and Gábor Klaniczay since the 1980s has been an extended effort at source exploration and the resulting source publication, amounting to more than 6,000 pages. This work brings to light the various documents on witch hunting in Hungary in the early modern period, providing ample source material for folklore studies, historical research, as well as more generally for the humanities. The volume to be reviewed below is a collection of papers in English translation, covering 412 pages. ${ }^{1}$

In the introduction the editors refer to this source publication effort as one of the most important achievements of the last three decades. The authors also warn, however, that, compared to the amount of published source material available, there is still a relative shortage of comprehensive studies of witchcraft in Hungary, particularly as regards works of a monographic standing written in languages that would render them accessible to international research. This is why it is with great joy that we note that the volume Witchcraft and Demonology in Hungary and Transylvania was published by one of the most influential and prestigious platforms of contemporary international witchcraft research, the Historical Studies in Witchcraft and Magic series by Palgrave. Neither this excellent collection of papers, nor the recent body of relevant research could have been produced without the help of the Vernacular Religion on the Borders of Eastern and Western Christianity: Continuity, Change and Interactions research project (ERC project No. 324214) which operated between 2013 and 2018 under the leadership of Pócs and which brought great momentum to the work of the witchcraft research team.

Although the volume is not a monograph in the classic sense, the eight papers it contains provide an excellent representative selection of the achievements of recent scholarship, faithfully reflecting the main directions of research pursued in Hungary, the complex problems related to witchcraft and the concomitant methodological dilemmas. The editorial introduction (pp. 3-5), before offering a summary of each paper, first briefly describes the political and historical conditions of Hungary in the early modern period and the ratios of the various religious denominations, thus providing sufficient context for readers who are not well acquainted with the period and the area.

It may come as something of a surprise that the first paper introducing the volume is the translation of a book chapter written almost 25 years ago - chapter 5 of Ildikó Sz. Kristóf's book “Ördögi mesterséget nem cse-

\footnotetext{
* The research leading to these results received funding from the European Research Council under the European Union's Seventh Framework Programme (FP7/2007-2013)/ERC grant agreement No. 324214.
} 
lekedtem": a boszorkányüldözés társadalmi és kulturális háttere a kora újkori Debrecenben és Bihar vármegyében ("Mine was no Devilish Craft": The Social and Cultural Background of Witch-Hunting in Debrecen and Bihar County in the Early Modern Period). This chapter was written in the early 1990s and published in 1998 (Kristóf 1998). The author places this earlier work into context by adding a brief introduction, making the reader aware that the paper is meant to represent the research scene of the Hungary of the post-communist transition years. This book by Kristóf is indeed the only work of micro-history and historical anthropology to date to use a broad range of contextual source material in order to explore the witchcraft accusations of an entire region (Bihar County) and a large city (Debrecen). In the present case, however, we may fairly ask the question what value, beyond paying an old debt, does this paper convey to an international audience in 2017, in the context of the present volume? In the chapter "The Social Background of Witchcraft Accusations in Early Modern Debrecen and Bihar County" (pp. 13-89) the author discusses the origin of witchcraft accusations, the 'bottom up' view of witch hunting. This extremely detailed source exploration and analysis shows how many different types of relationship can exist between the bewitchment narratives contained in the documentation of witchcraft trials and reality. As regards methodology, the chapter, and indeed the entire book, supports the claim that exploring contextual sources is absolutely indispensable for understanding the nature of these accusations and to map the way in which witchcraft accusations emerge; the trial documentation in itself is insufficient to understand the phenomenon of witchcraft accusations in the early modern period. If Kristóf's present paper has stood the test of time, this is due to its meticulous historical research, the inclusion of several viewpoints and the fact that she offers what Clifford Geertz (1973) called thick description. In her interpretation of events the author successfully resisted the temptation to force her material into reductive models. Instead she enables the reader to appreciate the true complexity of witchcraft accusations and shows that these accusations actually reflect a whole range of complex dynamics of the society in which they emerged.

László Pakó continues along the tracks set out not only by Kristóf, but also by his predecessor, Kolozsvár (today: ClujNapoca) historian and archivist András Kiss, concerning the exploration of contextual sources. In his case study "Witchcraft, Greed and Revenge: The Prosecutorial Activity of György Igyártó and the Witch Trials of Kolozsvár in the 1580s" (pp.91-109) Kiss retraces the steps of a single procurator from Kolozsvár, pointing out how individual motivations and the power games of a city could lead to one of the first massive waves of witch hunting at Kolozsvár in the late 16th century. Instead of choosing a bottom-up perspective, the author describes the urban elite setting and the culture of procurators in Transylvania in the early modern period, as well as the changing legal setting in which these trials, often leading to a lethal outcome, emerged. Essentially, he focuses on the activity and motivations of a single individual given to witch-hunting, György Igyártó by name. Although we have in-depth knowledge of several similar persecutors in the history of Western European witch hunting, until Pakó's writing Hungarian research lacked such an approach; apart from this his analysis draws attention to several important aspects of witch hunting. In his conclusion he claims that Igyártó's activity demonstrates that individual vindictiveness, grudges or greed can easily swell into institutionalised witch hunting without any particular ideological, political or economic motivation.

The following three papers in the volume constitute a unified block in the sense that they all discuss essential figures and roles within the phenomenon of witchcraft. 
Klaniczay explores healers, Judit Kis-Halas rural magic specialists, and Pócs examines táltos figures. ${ }^{2}$ This block leads us from works using approaches such as historical anthropology and micro-history on to broader cultural historical and folklore analysis. In view of this methodological shift it also becomes clear what type of question we may hope to answer satisfactorily through an analysis based mainly on witness statements in a witchcraft trial. Klaniczay and Kis-Halas place their theme in its closer and broader social historical context, but do not set out to explore the various agents who participated in the trials. In other words they refrain from exploring the micro-context of the events in question. Pócs, having no other existing sources, uses only the material of the witchcraft trials in an attempt to clarify the problem of Hungarian táltos in the 18th century. These works thus rely essentially on the research team's published witchcraft trial material - let us see with what results.

Klaniczay's paper "Healers in Hungarian Witch Trials" (pp. 111-158) aims to explore the nature of witchcraft accusations and is thus in line with the papers in the volume that have already been discussed. It seeks to find out who were the accusers and what sort of role healers played in these accusations. This question has long been the focus of both Hungarian and international literature, since healers have always featured highly among those accused. Accordingly, Klaniczay starts his paper with a brief, but extremely useful review of the relevant Hungarian research, then goes on to present dilemmas related to three towns (Kolozsvár, Hódmezővásárhely and its vicinity, Kiskunhalas). One important result of this analysis is that Hungarian data diverge from Western European models in that witchcraft conflicts involving healers played a far greater part in early modern Hungary. The author also finds it important to note that although being a professional healer exposed the practitioner to possible accusations of witchcraft, there were always plenty of healers who still managed to avoid being targeted in this way. These more fortunate figures who escaped being burnt at the stake typically did not live in the village or town concerned. Why? This question leads the author back to that earlier methodological conclusion whereby acquaintance with any given situation and the conditions in the given community are indispensable if we wish to understand the meaning of any particular accusation of witchcraft. Merely exploring the healing profession is far from satisfactory. The analysis of healers, on the other hand, confirms previous conclusions which stated that rivalry and strife between healers and midwives played an important part in the mechanism of accusation, since in addition to clerical demonologists and official witch hunters they were the most important agents in sustaining the ideology of witchcraft (cf. Briggs 1989; 1996). Based on these three cross sections we see that in 16th-century Kolozsvár most of those accused were in fact professional healers. In early 18th century Hódmezővásárhely or Kiskunhalas there were no actual healing practices underlying most healing accusations. This change may be interpreted as the institutionalisation of accusation.

The primary goal of Pócs' and Kis-Halas' studies is not to understand and analyse the emergence of accusations of witchcraft. Rather, documents of witchcraft accusations provide an unparalleled opportunity, indeed they are often the only opportunity to gain an insight into the popular culture and everyday life of the early modern period, and thus are of interest to a broader public, going well beyond the perspective of witchcraft accusations. Kis-Halas offers the most thorough exploration possible of specialists in popular witchcraft by examining three periods in the history of the city of Nagybánya (today Baia Mare), for which sources are plentiful, in a piece of synchronous historical research. Her "Divinatio Diabolica and Superstitious Medicine: Healers, Seers and Diviners in the Changing 
Discourse of Witchcraft in Early Modern Nagybánya" (pp. 159-219) paper focuses on the 'medical market', i.e. rural specialists in magic and their clientele, and the relationship between these two groups. One of the novel features of this analysis is that the author tracks the use of words relating to rural magical specialists in the contemporary sources and the changes in meaning of these terms. These reflections reveal, among other things, that it is in the 17th century that participants in the trials begin to speak of a malevolent witch as a 'devil'. This leads the author to the conclusion that this shift is a symptom of the change described by Stuart Clark (2001 [1977]: 459-465) as starting in the 16th century specifically under the influence of an interpretation of disease used by Protestant demonology, whereby disease strikes humans by the will of the Christian God, and is thus not the result of human malevolence. It appears that in the first third of the 17th century this change also reached Nagybánya, where two theories explaining misfortune existed side by side. In Kis-Halas' interpretation the lawsuit against healers and midwives in the 1670s was a manifestation of the clash of these two interpretations in the public domain. The paper then goes on to analyse the relationship of healers and their patients, and finally offers a detailed description of the cases of three healers who pursued fairly different life careers.

Pócs' paper is not her first work on the Hungarian táltos - she has repeatedly explored this figure, with particular focus on the question of whether the Hungarian táltos may be considered a shaman or not. Since the publication of Carlo Ginzburg's much debated classic (see Ginzburg 1989; in English Ginzburg 1991), the questions of the broader connections surrounding European shamanism and witchcraft have been the target of lively international discourse, in which two camps, one of Ginzburg supporters and the other of his opponents, are clearly discernible. ${ }^{3}$ This is one reason why
Pócs' most recent writing can (also) expect to attract considerable international attention. In it she formulates her conclusions, in contrast to her previous research, on the basis of all the witchcraft trials that have been processed to date. The main question she addresses in her paper "Shamanism or Witchcraft? The Táltos Before the Tribunals" (pp. 221-289) is who the táltos actually is in the mirror of 18th century witchcraft trials and whether this táltos fits more readily into the mediating system of witchcraft, or of shamanism. At the same time, the true virtue of this chapter is not in classifying the Hungarian táltos as a member of one or other category in an artificial field of definitions which are themselves under constant modification. It seems that this question is in itself impossible to answer, as Pócs also concludes when she declares that the táltos was neither witch nor shaman, nor, possibly, either. Belief systems that are easy to discriminate clearly on the theoretical level will naturally have a great deal in common on the plane of practice. Therefore, the various elements can easily shift from one system into another and the researcher can also easily analyse phenomena as parts of one or other of the relevant systems.

Pócs proves satisfactorily on the basis of the available sources that while a táltos can easily become adapted to the system of witchcraft, particularly in the witch-hunting context of the age, at the same time they are more than mere witches. But then what and who was a 'real táltos'? The question inevitably remains rhetorical, but this actually turns out to be an advantage for the paper. To seek the táltos described by the 19th and 20th-century scholarship concerned with the ancient Hungarian religion and belief system in the witchcraft documents of the 18 th century is at least as problematic as it is to force the táltos into the system of shamanism or witchcraft. The image that emerges from the various fragmented sources about the 18th-century táltos is varied because these historical splinters do not form a uni- 
fied whole. Sometimes the táltos is seen to be healing; at other times he or she is fighting for his/her community, the next time he or she is merely an impostor out to find treasure. Sometimes he or she is a much respected member of the community, at other times a fraud exposed to public ridicule. The most important finding of the paper is precisely this, that even communities that are close to each other in time or space speak of the táltos using a varied and dynamic discourse, depending on its momentary socio-cultural micro-context and the traditions of local society. Although Pócs mobilises all possible means to find the 'real táltos', nevertheless the paper leads its reader to conclude that there is no 'genuine táltos-ness', there is no 'real táltos', there are only different individual táltos.

The chapters by Péter Tóth G. and Dániel Bárth do not concern themselves with the analysis of witness statements from witchcraft trials. Both authors focus on the 18th century, the end of the early modern period in the broad sense, discussing witch hunting in the context partly of Hungarian Catholic demonology (Bárth) and partly in the legal historical context of everyday institutional usage and legal custom (Tóth G.). Both of these works respond to a felt absence - why in spite of such a large amount of systematic effort at exploring and publishing case materials is it still so difficult to write monographic works about a single city, region or period? The answer is that there is a large amount of fundamental research in legal history and demonology still waiting to be carried out.

Tóth G.'s paper “The Decriminalization of Magic and the Fight Against Superstition in Hungary and Transylvania, 1740-1848" (pp. 291-317) seeks to answer the seemingly simple questions of why the persecutions ended and, once they were terminated in the legal sense, why did they continue in practice? Tóth G. argues that a partial explanation should be sought in part in the fact that legal customs and practice had become routine and supports it by showing plausibly how a law, once it came into force, finally made its way to the executive bodies. In his analysis he points out some essential differences between Royal Hungary and the Transylvanian Principality. Explanation based on events is only one side of the coin according to the author. He also deploys the methods of statistics and content analysis in order to attain a more complex answer. In order to build good statistics and produce clear distinctions between different regions one must be familiar with the entire source material. This is where recent extensive efforts to explore and publish trial material prove most useful - without them it would be impossible to answer the questions asked by Tóth G. Finally, the analysis of the relevant legislation completes the picture. According to the summary offered by the author, the new legislation brought changes in the legal categories that codified magical activities, the meaning of these activities and the relevant penal sanctions. Witchcraft was redefined as a medical category, a form of mental derangement, and as such, psychotics could not be condemned using a legal procedure. The end of the witch hunts and their continuation despite the legal ban has a broad literature to date. Tóth G. does not discuss this literature in the present paper, but in any further research it would be important to place the early modern Hungarian findings in this broader context.

Bárth's writing is practically the only representative in the volume of the 'demonology' section mentioned in the title. Compared to Western European scholarship where analyses of witchcraft using the perspective of early modern demonology were almost in a majority for a while, the paper "Demonology and Catholic Enlightenment in Eighteenth-Century Hungary" (pp. 319-347) points to the fact that Hungarian Catholic demonological literature has gone entirely unprocessed. Consequently, Bárth's writing is more of a programmatic piece, a kind of outline for future research, rather 
than a summary of the subject area, despite its title. The author is mainly interested in changes in the Catholic church's attitude to vernacular culture. In order to capture this, he devotes particular attention to the role of the lower clergy. Bárth claims that it is indispensable to examine the measures and activity of the priests active in villages and small towns if we wish to understand the complex interrelations between clerical enlightenment and vernacular culture. In this paper he compares the Franciscan exorcist from Zombor Rochus Szmendrovich with the German-speaking exorcist witch doctor Johann Joseph Gassner in order to map out certain central themes that can serve as points of departure for later research with a broader scope, possibly even for anthropologists analysing 21st-century instances of exorcism.

The closing paper of the volume, "Talking Through Witchcraft - on the Bewitchment Discourse of a Village Community" (pp. 349-393) by Ágnes Hesz may at first sight appear to be the odd one out as it is the only piece that does not use historical sources, nor does it focus on the early modern period. The author analyses and interprets the experiences she gathered during repeated stretches of field work carried out in an ethnic Hungarian village in Romania starting in the early 2000s. It becomes clear that the paper rhymes with that of Sz. Kristóf, exploring very similar problems to those raised in the first paper of the volume. Writing about her anthropological fieldwork Hesz describes how bewitchment can function as a discourse, a kind of shared language, and how this cultural idiom serves to manage and communicate certain types of social tension and individual tragedies. For this very reason, the author often enters into a fruitful discussion with the works of Jeanne Favret-Saada (for example 1977), who was the first to interpret witchcraft as discourse, just as Sz. Kristóf did in connection with her own interpretation of historical material. Long-term anthropological fieldwork carried out over the course of several years in the community enables the author to see the phenomenon she explores in an extremely detailed and nuanced fashion. While the historian is compelled to work with tiny fragments of history which appear as so many still photographs through the witness statements of the trials, the anthropologist, if she is lucky, may become witness to several manners of speaking, indeed she may involuntarily provoke or build such instances. We learn from anthropological knowledge thus acquired that witchcraft discourse changes perpetually and dynamically based on individual interests, social relations and situations and is thus malleable and variable. Hesz pays particular attention to the phenomenon of gossip as an important factor in shaping this discourse. The anthropological literature on witchcraft had an inspiring effect on historical research from the start and there can be no doubt that Hesz' paper, which integrates the findings of the author's own field work with the historical literature, will serve as another new and important point of departure for historical investigations. ${ }^{4}$

Contemporary international witchcraft research, as the present volume also demonstrates, is extremely complex and versatile, making it difficult to pick out one or two main strands. Works written in the spirit of micro-history or historical anthropology continue to play an important part, as do efforts to understand the deeper meaning of local accusations. At the same time, efforts to explore connections and differences between healers, specialists in magic, or in shamanism and witchcraft also continue. Alongside all of this, a strand which has only gained momentum recently is that of studying the history of the end of the persecutions, the history of witchcraft in the 19th and 20th centuries. There are even a few laudable studies based on fieldwork in contemporary Europe..$^{5}$ Thus, Witchcraft and Demonology contains papers that are engaged in active discourse with 
current trends in international witchcraft research and actually question, at a number of points, their conclusions, applicability or scope of validity. From a methodological point of view, the volume inspires reflection on questions such as: what is the range of research and questioning which the witchcraft trial documentations are suited for in themselves, and what are the new considerations and reflections that contemporary anthropological research and historical research into early modern sources can provide? Publishing chapters with various interdisciplinary approaches in one and the same volume renders extremely fertile the interpretation of that ever so elusive and undefinable concept which we simply term witchcraft.

Emese Ilyefalvi

(Department of Folkloristics, Eötvös Loránd University, Hungary; Wirth Institute for Austrian and Central European Studies, University of Alberta, Canada)

\section{Notes}

1 The English edition is based on the Hungarian volume Boszorkányok, varázslók és démonok Közép-Kelet-Európából edited by Éva Pócs and Gábor Klaniczay (2014). The only exceptions are the papers by Ildikó Sz. Kristóf and Ágnes Hesz.

2 According to Pócs (p. 222) the Hungarian táltos is a "mediator who can contact the supernatural world and as such belongs to the category of wise men/women, seers, and sorcerers with occult skills."

3 Likewise, the editors of Witchcraft and Demonology also hold different opinions regarding the question.

4 See further Geschiere 2013.

5 Cf. Mencej 2017.

\section{References}

Briggs, Robin. 1989. Communities of Belief: Cultural and Social Tensions in Early Modern France. Oxford: Clarendon Press.

Briggs, Robin. 1996. Witches \& Neighbours: The Social and Cultural Context of European Witchcraft. London: Harper Collins.

Clark, Stuart. 2001 [1977]. Thinking with Demons: The Idea of Witchcraft in Early Modern Europe. Oxford: Clarendon.

Favret-Saada, Jeanne. 1977. Les mots, la mort, les sorts: La sorcellerie dans le Bocage. Paris: Gallimard.

Geertz, Clifford. 1973. Thick Description: Toward an Interpretive Theory of Culture. - The Interpretation of Cultures: Selected Essays. New York, NY: Basic Books, 3-30.

Geschiere, Peter. 2013. Witchcraft, Intimacy, and Trust: Africa in Comparison. Chicago, IL: University of Chicago Press. DOI: https://doi. org/10.7208/chicago/9780226047751.001.0001.

Ginzburg, Carlo. 1989. Storia notturna: Una dezifrazione del Sabba. Torino: Einaudi.

Ginzburg, Carlo. 1991. Ecstasies: Deciphering the Witches' Sabbath. New York, NY: Pantheon Books.

Kristóf, Ildikó. 1998. “Ördögi mesterséget nem cselekedtem". A boszorkányüldözés társadalmi és kulturális háttere a kora újkori Debrecenben és Bihar vármegyében. Debrecen: Ethnica.

Mencej, Mirjam. 2017. Styrian Witches in European Perspective Ethnographic Fieldwork. London: Palgrave Macmillan. DOI: https://doi. org/10.1057/978-1-137-37250-5.

Pócs, Éva and Gábor Klaniczay, eds. 2014. Boszorkányok, varázslók és démonok Közép-KeletEurópából. Budapest: Balassi Publisher House. 